\title{
Prevalence of Advanced, Precancerous Colorectal Neoplasms in Black and White Populations: A Systematic Review and Meta-analysis
}

Thomas F. Imperiale, $\mathrm{MD}^{1-3}$, Priya R. Abhyankar, BS ${ }^{1}$, Timothy E. Stump, MA ${ }^{4}$, Thomas W. Emmett, MD, MLS ${ }^{5}$

${ }^{1}$ Division of Gastroenterology and Hepatology, Department of Medicine, Indiana University School of Medicine, ${ }^{2}$ Health Services Research and Development, Richard L. Roudebush VA Medical Center, ${ }^{3}$ Regenstrief Institute, Inc. ${ }^{4}$ Department of Biostatistics, Indiana University School of Medicine, ${ }^{5}$ Ruth Lilly Medical Library, Indianapolis, IN.

Running Title: Advanced Colorectal Neoplasia in Blacks and Whites

Word count (abstract): 245

Word count (main text): 2492

Word count (main text; references; table/figure legends): 4760

Number of figures: 3

Number of tables: 3

Number of tables in appendix: 1

Corresponding author:

Thomas F. Imperiale, MD

Indiana University Medical Center

Regenstrief Institute

1100 West $10^{\text {th }}$ Street

Indianapolis, IN 40202

TEL: 317-274-9046

FAX: 317-274-9304

E-mail: timperia@iu.edu

The authors report no conflicts of interest.

Author contributions to manuscript:

Study conception: $\mathrm{TI}$

Obtained funding: TI

Data collection: PA, TE, TI

Data abstraction: PA, TI

Technical, or material support: $\mathrm{TI}$

Study quality assessment: PA, TI

Analysis: TS

Drafting of the article: TI

Editing of the manuscript: all

Final approval of the manuscript: all

Study supervision: $\mathrm{TI}$ 
Funding Source: This project was supported by Indiana CTSI Collaboration in Translational Research Grants (Grant \#UL1TR001108)

\begin{abstract}
:
Background \& Aims: Colorectal cancer (CRC) incidence and mortality are higher in black vs white populations. The reasons for these disparities are not clear, yet some guidelines recommend screening black persons for CRC starting at ages 40-45 years. We performed a systematic review and meta-analysis to compare the prevalence of advanced adenomas (AAs) and advanced, precancerous colorectal neoplasms (ACNs) between asymptomatic black and white screen-eligible adults.
\end{abstract}

Methods: We searched Ovid MEDLINE, PubMed, Embase, and the Cochrane Library to identify articles (published from 1946 through June 2017) that reported prevalence values of AA or ACN in average-risk black and white individuals undergoing screening colonoscopy. Two authors independently assessed study quality and risk for bias using a modified validated quality assessment instrument. Following the PRISMA guidelines, 2 authors independently abstracted descriptive and quantitative data from each study. We performed a random effects meta-analysis to determine risk differences and odds ratios (ORs).

Results: From 1653 articles, we identified 9 studies for analysis, comprising 302,128 individuals. Six of the 9 studies were of high methodological quality, had a low risk for bias, and were included in the meta-analysis. In these 9 studies, the overall prevalence values for AA and ACN did not differ significantly between back (6.57\%) and white screened individuals $(6.20 \%$; OR, $1.03 ; 95 \%$ CI, 0.81-1.30). Among a subgroup of 5 studies, the prevalence of proximal AA and ACN was significantly higher in black (3.30\%) than in white screened individuals $(2.42 \%$; OR, 1.20; 95\% CI, 1.12-1.30). Excluding the largest study did not affect overall prevalence (OR, 0.99 ; CI, 0.73-1.34) but eliminated the difference in prevalence of proximal AA or ACN (OR, $1.48 ; 95 \%$ CI, 0.87-2.52).

Conclusions: In a meta-analysis, we found the overall prevalence of AA and ACN did not differ significantly between average-risk black and white persons, indicating that the age at which to begin CRC screening need not differ based on race.

Key words: colon cancer; incidence; ethnicity differences; colonoscopic detection 


\section{INTRODUCTION}

Although colorectal cancer (CRC) is the third most common cancer and the second-leading cause of cancer death in the U.S. among all racial/ethnic groups, higher CRC incidence and mortality rates are found among Black adults. ${ }^{1}$ In 2014, the U.S. incidence of colorectal cancer was 50.4 per 100,000 for Black men, as compared with 43.0 per 100,000 for White men ${ }^{2}$. Incidence rates were lower for women, but were higher for Black women (38.9 per 100,000 versus 32.8 per 100,000 for White women). ${ }^{2}$ A similar discrepancy exists for CRC mortality: 23.1 per 100,000 for Black men vs.16.4 per 100,000 for White men, and 15.3 per 100,000 for Black women vs. 11.7 per 100,000 for White women. ${ }^{2}$ Because of the higher incidence and mortality rates in Blacks, the American College of Gastroenterology and the U.S. Multi-Society Task Force on Colorectal Cancer recommend CRC screening beginning at 45 years for average-risk Blacks, while the American College of Physicians recommends starting at age 40, five to ten years earlier than for non-Blacks. ${ }^{3-6}$ Several reasons for this racial disparity are offered. Some studies suggest genetic / biological differences, while others point to social, environmental, or behavioral differences, including disparities in rates of CRC screening. ${ }^{7-9}$

The immediate precursor to $C R C$ is the advanced adenoma (AA), the current target lesion for screening. ${ }^{3}$ AAs usually include an adenoma $1 \mathrm{~cm}$ or larger, or one with villous histology or high-grade dysplasia, regardless of size. This combination of findings is also referred to as advanced precancerous polyps or neoplasms and sometimes includes sessile serrated polyps 1 $\mathrm{cm}$ or larger. When AA or advanced, precancerous polyps are combined with $\mathrm{CRC}$, the term "advanced colorectal neoplasia" or "advanced neoplasia" is used.

The published literature comparing AA prevalence in Blacks and Whites is inconsistent. A difference in AA prevalence between Blacks and Whites could lend support to biology / genetics 
as a contributor to the incidence / mortality disparity, whereas no difference would suggest nonbiological factors such as access to and uptake of screening, or behavioral or social differences in response to symptoms. The purpose of this systematic review was to compare the prevalence of $A A$ or advanced, precancerous colorectal neoplasms (ACN) between Blacks and Whites.

\section{METHODS}

This study was conducted on the campus of Indiana University Purdue University at Indianapolis from May to August 2017 without the need for approval by the Institutional Review Board of Indiana University. We report methods and results consisted with the Preferred Reporting Items for Systematic Reviews and Meta-Analyses (PRISMA) format. ${ }^{10}$

Data Sources and Searches. A comprehensive search of the literature was performed by a medical librarian (TWE) using Ovid MEDLINE, PubMed, Embase, the full Cochrane Library, and ClinicalTrials.gov. Searches were performed in June 2017, and all databases were searched from inception. Bibliographies of relevant studies were reviewed for additional references. Search strategies for the four databases are displayed in the Appendix. Database-specific subject headings and keyword variants for each of the four main concepts - colorectal disease, precancerous conditions, and the black and white populations - were identified and combined. Results were limited to the English language.

Study Selection. We included studies measuring the prevalence of advanced adenomas (AA) or advanced colorectal neoplasia $(\mathrm{CRC}+\mathrm{AA})$ in average-risk Blacks and Whites undergoing screening colonoscopy. 
Data Extraction and Quality Assessment. Two authors independently abstracted descriptive and quantitative information from the studies. Study quality and risk of bias were assessed using a modified version of the National Institute of Health's Quality Assessment Tool for Observational Cohort and Cross-Sectional Study. ${ }^{11}$ This instrument was modified to make it more relevant for cross-sectional research, resulting in the need to assess each article for 9 of the instrument's 14 questions. ${ }^{11}$ Thus, study quality could range from 0 to 9 . Disagreements in ratings were resolved in discussion. The quality criteria for the modified tool are found in the first column of Table 1.

Data Synthesis and Analysis. Study homogeneity was quantified using the $\mathrm{I}^{2}$ statistic, which quantifies the percent of variation across a group of studies that is due to heterogeneity rather than chance. ${ }^{12} \mathrm{~A}$ random effects model was used to combine data on AA/ACN prevalence from individual studies using $\mathrm{R}$ software and metafor $\mathrm{R}$ package for meta-analysis. ${ }^{13,14}$ Prevalence point estimates, and risk differences and odds ratios with 95\% confidence limits were generated. A funnel plot and regression test for asymmetry for overall AA/ACN prevalence were generated to assess this body of literature for publication bias. ${ }^{15}$ Prior to performing the analyses, we decided to include two subgroup analyses based on study design features. In one subgroup analysis, we would exclude the largest study for two reasons: 1) it was the largest study by far and was expected to have a large and numerically-important influence on aggregate risk estimates; 2) it was the only study without polyp histology. The second subgroup analysis would include the studies with highest study quality and lowest risk for bias

Role of the Funding source. The study was funded by the Indiana CTSI Collaboration in Translational Research Grants. The funding source had no role in the study's design, conduct of the review, or reporting. 


\section{RESULTS}

A total of 1653 references were identified. After removal of 128 duplicates, 1525 unique titles and abstracts were reviewed. From 1525 titles, we excluded 1363 for various reasons (Figure 1) and reviewed 162 full text articles. Of the 162 articles, 153 were excluded (Figure 1), leaving 9 studies that met all inclusion criteria and no exclusion criteria. ${ }^{16-24}$

Descriptive characteristics of the 9 studies are shown in Table 2. The 9 articles included 302,128 participants and were published between 2010 and 2017. Individual study sample sizes ranged from 80 to 292,494 . The objective of 7 studies was to quantify the prevalence of advanced adenomas in both racial groups. All studies were cross-sectional, 5 of which collected data prospectively. ${ }^{16,19,21-23}$ Six studies involved single sites, ${ }^{16-18,20-22}$ while the remaining three ${ }^{19,23,24}$ were multisite studies, one of which ${ }^{19}$ included 84 practices throughout the U.S. All study populations were average-risk. The criteria for advanced adenoma were comparable across studies except for the largest study, which used "polyp > 9 mm" without including polyp histology. ${ }^{19}$ For this analysis, we assumed that all such polyps were advanced adenomas. One study did not provide a definition for advanced adenoma. Large serrated polyps were included in the definition of advanced adenoma in two studies. ${ }^{20,23}$ All studies defined "proximal" as the splenic flexure and colon segments proximal to it. Six studies reported no differences in AA prevalence between Blacks and Whites, 1 study reported a higher AA prevalence in Whites, 1 study reported higher prevalence in Blacks, and 1 reported a higher prevalence of large polyps in Blacks.

Study quality was generally high, with scores between 7 and 9, out of a highest achievable score of 9 (Table 1). Six of 9 studies were of high methodological quality, with low-risk for 
bias. ${ }^{17-21,23}$ The three studies with high-risk for bias ${ }^{16,22,24}$ did not adjust prevalence for age and sex, a critical feature for a valid comparative analysis.

Advanced adenoma (AA) / advanced colorectal neoplasia (ACN). Among the 9 studies, prevalence of AA/ACN ranged from $2 \%$ to $10 \%$ for Whites and $5 \%$ to $12 \%$ for Blacks (Table 3 ). Results of individual studies for AA/ACN are shown in Figure $\mathbf{2 a}$. Only the study by Lieberman and colleagues, ${ }^{19}$ for which no histology was available, showed a higher prevalence of AA/ACN in Blacks. The study by Schroy and colleagues ${ }^{21}$ showed that Whites had a higher prevalence of $A A / A C N$. In aggregate, however, there was no difference in $A A / A C N$ prevalence between Blacks and Whites, with respective point prevalences of $6.57 \%$ and $6.20 \%$, an odds ratio of 1.03 $(95 \% \mathrm{Cl}, 0.81-1.30)$ and absolute risk difference of $0.00(95 \% \mathrm{Cl},-0.01$ to 0.02$)$ (Table 3). The $\mathrm{I}^{2}$ values indicate moderate heterogeneity among studies. These findings remained unchanged with the largest study ${ }^{19}$ excluded and in the subgroup of 5 studies ${ }^{17,18,20,21,23}$ ("best subset") in which the results in each individual study were adjusted for age and sex (Table 3). $\mathrm{I}^{2}$ values for these two subgroups reflect low-to-moderate study heterogeneity.

Proximal AA/ACN. Among the 5 studies in which advanced proximal lesions were measured, ${ }^{16,18,19,21,23}$ the prevalence ranged from $0 \%$ to $4 \%$ for Whites and from $2 \%$ to $9 \%$ for Blacks. Individual study results for proximal AA/ACN are shown in Figure $\mathbf{2 b}$. Two ${ }^{18,19}$ of 5 studies showed greater prevalence in Blacks, one of which was the study by Lieberman and colleagues. ${ }^{19}$ In aggregate, due to the dominance of the Lieberman study, proximal AA/ACN was more common among Blacks, with point prevalences of $3.30 \%$ in Blacks and $2.42 \%$ in Whites, an odds ratio of $1.20(95 \% \mathrm{Cl}, 1.12-1.30)$, and absolute risk difference of $0.01(95 \% \mathrm{Cl}$, 0.00 to 0.01$)$. The $\mathrm{I}^{2}$ test showed no study heterogeneity (0\%). Exclusion of the Lieberman study increased heterogeneity to the low-to-moderate range and eliminated the difference in proximal $\mathrm{AA} / \mathrm{ACN}$ prevalence, but with less precision: $\mathrm{OR}=1.48 ; 95 \% \mathrm{Cl}, 0.87-2.52$ ) and risk difference 
of $0.007(95 \% \mathrm{Cl},-0.004$ to 0.018$)$. In the best subset of 3 studies ${ }^{18,21,23}$, which had a moderate degree of heterogeneity, there was no difference in prevalence: $\mathrm{OR}=1.44(\mathrm{Cl}, 0.84-2.49)$, risk difference of $0.006(\mathrm{Cl},-0.005$ to 0.018$)$ (Table 3). A funnel plot for overall prevalence of AA/ACN did not suggest publication bias $(P=0.52)$ (Figure 3 ).

\section{DISCUSSION}

In this systematic review of 9 studies of screening colonoscopy involving more than 300,000 subjects, we found no difference in the prevalence of advanced precancerous neoplasia between Blacks and Whites. This main finding among all studies was maintained in subgroup analyses that excluded the largest study and included only the highest quality studies. Further, five of the studies examined differences in the prevalence of advanced, precancerous neoplasia in the proximal colon, among which Blacks had a higher prevalence - an absolute risk difference of $1 \%$ and a 1.20 times greater odds than Whites. This small difference was not maintained in subgroup analyses. Among all studies, the degree of heterogeneity by $I^{2}$ test ranged from none to moderate.

Our findings are consistent with most, but not all, of the previous studies on this topic. We applied specific inclusion and exclusion criteria to identify those studies in which colonoscopy was the screening modality used in average-risk Blacks and Whites. Study quality and risk for bias were assessed in a standard fashion using an adapted validated instrument and independent review by two study authors. Study quality was moderate to high, with only three studies having high-risk for bias resulting from lack of adjustment for demographic covariates of age and sex. The consistency of the quantitative findings for any advanced precancerous neoplasia suggest that the finding of no difference is robust. For proximal advanced precancerous neoplasia, the overall difference was clinically small and was not supported by 
pre-specified subgroup analyses. In total, our findings indicate no differences in advanced, precancerous neoplasia between average-risk Black and White screen-eligible adults.

Our findings are consistent with those from a VA-based, multi-site, retrospective, cross-sectional analysis of nearly 91,000 Veterans, in which the prevalence of CRC was slightly higher in Blacks (1.5\% vs. $1.4 \%$ in Whites; adjusted $\mathrm{OR}=1.29$; $\mathrm{Cl}, 1.11-1.51)$ but with no difference in prevalence of advanced adenomas between Blacks and Whites (9.0\% vs. 9.4\%, respectively; adjusted $\mathrm{OR}=1.00 ; \mathrm{Cl}, 0.94-1.07) .{ }^{25}$ An analysis of $\mathrm{CRC}$ survival among Veterans extends the observation of "no difference" between Blacks and Whites, as Dominitz and colleagues compared outcomes in Black and White male veterans with a new diagnosis of $\mathrm{CRC}$, finding no difference in rates of surgical resection, radiation, chemotherapy, or 5 -year survival. ${ }^{26}$ Finally, the Delaware experience of resolution of the disparity in CRC incidence and mortality as the CRC screening disparity closed nicely illustrates how equalizing CRC screening rates between Blacks and Whites eliminated differences in CRC incidence, disease stage, and mortality. ${ }^{27}$

This analysis has strengths and limitations that warrant comment. One strength is the large sample size, despite the fact that one study accounted for nearly $97 \%$ of the observations. Another strength is the specificity of the study selection process, which resulted in a clinically homogeneous body of literature for analysis that was low-to-moderate in its degree of statistical heterogeneity. Study quality was moderate to high, as determined by a validated instrument. Finally, the quantitative findings were consistent in subgroup analyses, suggesting robustness of the numerical findings. A limitation of this analysis is the lack of adjustment of prevalence estimates for age and race in three studies, covariates that may have created imbalance in prevalence estimates between Black and White subjects in these studies. As mentioned, however, results were stable in subgroup analysis, suggesting that any imbalances due to unadjusted demographic features were not clinically important. A second limitation was the 
inability to adjust for other factors associated with CRC and/or advanced neoplasia such as BMI, cigarette smoking, certain medications (NSAIDs, aspirin, statins) and other behavioral features, as these factors could further confound prevalence estimates. Publication bias is a potential third limitation, which we believe is unlikely, as the funnel plot does not support it, and six of nine studies show no difference in AA/ACN prevalence between Blacks and Whites.

Based on our findings and those of other studies, a practical clinical issue is whether Blacks should be screened earlier than Whites, as some guideline organizations recommend. ${ }^{3,4,28} \mathrm{We}$ found no difference between Blacks and Whites in the prevalence of AN, largely comprised of advanced precancerous polyps, which is the precursor lesion for most CRC. Absence of a difference in AN prevalence suggests that the differences in CRC incidence and mortality are less likely due to biology and more likely due to behavioral or sociocultural differences in recognition of symptoms, need for diagnostic evaluation, and/or access to, acceptance or uptake of preventive services. Our findings, along with other studies on this topic, ${ }^{17,29-33}$ suggests that the age at which to begin screening need not differ based on race, especially in settings where obstacles to care are mitigated. However, for settings in which access to care disfavors Blacks, beginning screening in Blacks prior to age 50 may help mitigate this disparity.

A final consideration is the recent recommendation by the American Cancer Society to start average-risk screening in everyone at age $45 .{ }^{34}$ If this recommendation is followed broadly, it would lessen the clinical and policy implications of our findings. However, the uptake of this recommendation is yet to be determined, as it differs from those of all other professional organizations. $^{3-5}$ 


\section{CONCLUSION}

In conclusion, we found no difference in the prevalence of advanced precancerous neoplasia between average-risk, screen-eligible Blacks and Whites who underwent screening colonoscopy. Further, among the most rigorous studies, there was no difference in advanced neoplasia in the proximal colon. In areas without disparities in access to screening, our findings support eliminating the age difference at which to begin average-risk screening that is currently recommended by some guideline organizations, and beginning average-risk screening at age 50 regardless of race. To the extent that the advanced adenoma is the precursor lesion for $\mathrm{CRC}$, tailoring the age at which to begin screening and how to screen based on race is not supported by our findings. 


\section{REFERENCES}

1. Siegel RL, Miller KD, Fedewa SA, et al. Colorectal cancer statistics, 2017. CA Cancer J Clin. 2017;67(3):177-193.

2. Division of Cancer Prevention and Control CfDCaP. Colorectal Cancer Rates by Race and Ethnicity. Statistics Rates by Race and Ethnicity 2017. https://www.cdc.gov/cancer/colorectal/statistics/race.htm. Accessed September 25, 2017.

3. Rex DK, Boland CR, Dominitz JA, et al. Colorectal cancer screening: Recommendations for physicians and patients from the US Multi-Society Task Force on Colorectal Cancer. Am J Gastroentero. 2017;112(7):1016-1030.

4. Qaseem A, Denberg TD, Hopkins RH, Jr., et al. Screening for colorectal cancer: a guidance statement from the American College of Physicians. Ann Intern Med. 2012;156(5):378-386.

5. Bibbins-Domingo K, Grossman DC, Curry SJ, et al. Screening for Colorectal Cancer: US Preventive Services Task Force Recommendation Statement. JAMA. 2016;315(23):2564-2575.

6. Rex DK, Johnson DA, Anderson JC, et al. American College of Gastroenterology guidelines for colorectal cancer screening 2009 [corrected]. Am J Gastroenterol. 2009;104(3):739-750.

7. Albano JD, Ward E, Jemal A, et al. Cancer mortality in the United States by education level and race. J Natl Cancer Inst. 2007;99(18):1384-1394.

8. Doubeni CA, Major JM, Laiyemo AO, et al. Contribution of behavioral risk factors and obesity to socioeconomic differences in colorectal cancer incidence. J Natl Cancer Inst. 2012;104(18):13531362.

9. Chu KC, Miller BA, Springfield SA. Measures of racial/ethnic health disparities in cancer mortality rates and the influence of socioeconomic status. J Natl Med Assoc. 2007;99(10):1092-1100, 1102-1094.

10. Liberati A, Altman DG, Tetzlaff J, et al. The PRISMA statement for reporting systematic reviews and meta-analyses of studies that evaluate health care interventions: explanation and elaboration. PLoS medicine. 2009;6(7):e1000100.

11. NIH: National Heart, Lung, and Blood Institute. Quality Assessment Tool for Observational Cohort and Cross-Sectional Studies. Study Quality Assessment Tools 2014; https://www.nhlbi.nih.gov/health-pro/guidelines/in-develop/cardiovascular-riskreduction/tools/cohort. Accessed May 24, 2017.

12. Higgins JP, Thompson SG, Deeks JJ, Altman DG. Measuring inconsistency in meta-analyses. BMJ (Clinical research ed). 2003;327(7414):557-560.

13. Team RC. R: A language and environment for statistical computing [Internet]. Vienna, Austria: R Foundation for Statistical Computing; 2014. 2015.

14. Viechtbauer W. Conducting Meta-Analyses in R with the metafor Package. Journal of Statistical Software. 2010;36(3):1-48.

15. Egger M, Davey Smith G, Schneider M, Minder C. Bias in meta-analysis detected by a simple, graphical test. BMJ (Clinical research ed). 1997;315(7109):629-634.

16. Collazo TH, Jandorf L, Thelemaque L, Lee K, Itzkowitz SH. Screening Colonoscopy among Uninsured and Underinsured Urban Minorities. Gut and liver. 2015;9(4):502-508.

17. Friedenberg FK, Singh M, George NS, Sankineni A, Shah S. Prevalence and distribution of adenomas in black Americans undergoing colorectal cancer screening. Dig Dis Sci. 2012;57(2):489-495.

18. Lebwohl B, Capiak K, Neugut Al, Kastrinos F. Risk of colorectal adenomas and advanced neoplasia in Hispanic, black and white patients undergoing screening colonoscopy. Aliment Pharmacol Ther. 2012;35(12):1467-1473. 
19. Lieberman DA, Williams JL, Holub JL, et al. Race, ethnicity, and sex affect risk for polyps $>9 \mathrm{~mm}$ in average-risk individuals. Gastroenterology. 2014;147(2):351-358; quiz e314-355.

20. Mendelsohn RB, Winawer SJ, Jammula A, et al. Adenoma Prevalence in Blacks and Whites Having Equal Adherence To Screening Colonoscopy: The National Colonoscopy Study. Clin Gastroenterol Hepatol. 2017;15(9):1469-1470.

21. Schroy PC, 3rd, Coe A, Chen CA, O'Brien MJ, Heeren TC. Prevalence of advanced colorectal neoplasia in white and black patients undergoing screening colonoscopy in a safety-net hospital. Ann Intern Med. 2013;159(1):13-20.

22. Stein B, Anderson JC, Rajapakse R, Alpern ZA, Messina CR, Walker G. Body mass index as a predictor of colorectal neoplasia in ethnically diverse screening population. Dig Dis Sci. 2010;55(10):2945-2952.

23. Wallace K, Brandt HM, Bearden JD, et al. Race and Prevalence of Large Bowel Polyps Among the Low-Income and Uninsured in South Carolina. Dig Dis Sci. 2016;61(1):265-272.

24. Xirasagar S, Li YJ, Burch JB, Daguise VG, Hurley TG, Hebert JR. Reducing Colorectal Cancer Incidence and Disparities: Performance and Outcomes of a Screening Colonoscopy Program in South Carolina. Advances in public health. 2014;2014.

25. Imperiale TF, Imler TD, Kahi CJ, et al. Prevalence of Advanced Colorectal Neoplasia in Veterans: Effects of Age, Sex and Race. Gastroenterology. 2015;148(4):S-95.

26. Dominitz JA, Samsa GP, Landsman P, Provenzale D. Race, treatment, and survival among colorectal carcinoma patients in an equal-access medical system. Cancer. 1998;82(12):23122320.

27. Grubbs SS, Polite BN, Carney J, Jr., et al. Eliminating racial disparities in colorectal cancer in the real world: it took a village. J Clin Oncol. 2013;31(16):1928-1930.

28. Davila RE, Rajan E, Baron TH, et al. ASGE guideline: colorectal cancer screening and surveillance. Gastrointest Endosc. 2006;63(4):546-557.

29. Corley DA, Jensen CD, Marks AR, et al. Variation of adenoma prevalence by age, sex, race, and colon location in a large population: implications for screening and quality programs. Clin Gastroenterol Hepatol. 2013;11(2):172-180.

30. Laiyemo AO, Doubeni C, Pinsky PF, et al. Race and colorectal cancer disparities: health-care utilization vs different cancer susceptibilities. J Nat/ Cancer Inst. 2010;102(8):538-546.

31. Levitzky BE, Brown CC, Heeren TC, Schroy PC, 3rd. Performance of a risk index for advanced proximal colorectal neoplasia among a racially/ethnically diverse patient population (risk index for advanced proximal neoplasia). Am J Gastroenterol. 2011;106(6):1099-1106.

32. Lansdorp-Vogelaar I, van Ballegooijen M, Zauber AG, et al. Individualizing colonoscopy screening by sex and race. Gastrointest Endosc. 2009;70(1):96-108.

33. Lieberman DA, Holub JL, Moravec MD, Eisen GM, Peters D, Morris CD. Prevalence of colon polyps detected by colonoscopy screening in asymptomatic black and white patients. JAMA. 2008;300(12):1417-1422.

34. Wolf AMD, Fontham ETH, Church TR, et al. Colorectal cancer screening for average-risk adults: 2018 guideline update from the American Cancer Society. CA Cancer J Clin. 2018. 
Table 1. Quality Criteria and Risk of Bias for Included Studies

\begin{tabular}{|c|c|c|c|c|c|c|c|c|c|}
\hline Quality Criteria & $\begin{array}{l}\text { Collazo, } \\
2015^{16}\end{array}$ & $\begin{array}{l}\text { Friedenberg, } \\
2012^{17}\end{array}$ & $\begin{array}{l}\text { Lebwohl, } \\
2012^{18}\end{array}$ & $\begin{array}{l}\text { Lieberman, } \\
2014^{19}\end{array}$ & $\begin{array}{l}\text { Mendelsohn, } \\
2017^{20}\end{array}$ & $\begin{array}{l}\text { Schroy, } \\
2013^{21}\end{array}$ & $\begin{array}{l}\text { Stein, } \\
2010^{22}\end{array}$ & $\begin{array}{l}\text { Wallace, } \\
2016^{23}\end{array}$ & $\begin{array}{l}\text { Xirasagar, } \\
2014{ }^{24}\end{array}$ \\
\hline $\begin{array}{l}\text { Was the research question or objective } \\
\text { clearly stated? }\end{array}$ & Yes & Yes & Yes & Yes & Yes & Yes & Yes & Yes & Yes \\
\hline $\begin{array}{l}\text { Was the study population clearly specified } \\
\text { and defined? }\end{array}$ & Yes & Yes & Yes & Yes & Yes & Yes & Yes & Yes & Yes \\
\hline $\begin{array}{l}\text { Were all subjects selected or recruited from } \\
\text { the same or similar populations (including } \\
\text { the same time period)? }\end{array}$ & Yes & Yes & Yes & Yes & Yes & Yes & Yes & Yes & Yes \\
\hline $\begin{array}{l}\text { Were inclusion and exclusion criteria for the } \\
\text { study prespecified and applied uniformly? }\end{array}$ & Yes & Yes & Yes & Yes & Yes & Yes & Yes & Yes & Yes \\
\hline $\begin{array}{l}\text { Was a sample size justification, power } \\
\text { description, or variance and effect estimates } \\
\text { provided? }\end{array}$ & No & Yes & No & & No & Yes & No & No & No \\
\hline $\begin{array}{l}\text { Were age, sex, and race measured prior to } \\
\text { the outcomes being measured? }\end{array}$ & Yes & Yes & Yes & Yes & Yes & Yes & Yes & Yes & Yes \\
\hline $\begin{array}{l}\text { Were age, sex, and race clearly defined, } \\
\text { valid, reliable, and implemented } \\
\text { consistently? }\end{array}$ & $\begin{array}{l}\text { Yes } \\
\text { (self) }\end{array}$ & $\begin{array}{l}\text { Yes } \\
\text { (self) }\end{array}$ & $\begin{array}{l}\text { Yes } \\
\text { (self }\end{array}$ & $\begin{array}{l}\text { Yes } \\
\text { (endoscopists) }\end{array}$ & $\begin{array}{l}\text { Yes (not } \\
\text { stated) }\end{array}$ & $\begin{array}{l}\text { Yes } \\
\text { (not } \\
\text { stated) }\end{array}$ & $\begin{array}{l}\text { Yes (not } \\
\text { stated) }\end{array}$ & $\begin{array}{l}\text { Yes }(\text { not } \\
\text { stated) }\end{array}$ & $\begin{array}{l}\text { Yes }(\text { not } \\
\text { stated) }\end{array}$ \\
\hline $\begin{array}{l}\text { Were the outcome measures clearly } \\
\text { defined, valid, reliable, and implemented } \\
\text { consistently? }\end{array}$ & Yes & Yes & Yes & Yes & Yes & Yes & Yes & Yes & Yes \\
\hline $\begin{array}{l}\text { Critical: Were groups comparable at } \\
\text { baseline* or were differences in age and } \\
\text { sex adjusted? }\end{array}$ & No & Yes & Yes & Yes & Yes & Yes & No & Yes & No \\
\hline Point score: & 7 & 9 & 8 & 8 & 8 & 9 & 7 & 8 & 7 \\
\hline Risk of bias: & high & low & low & Low & low & low & high & low & high \\
\hline
\end{tabular}


Table 2. Descriptive Information from Included Studies

\begin{tabular}{|c|c|c|c|c|c|c|c|c|c|}
\hline $\begin{array}{l}\text { 1st Author, } \\
\text { Year (ref) }\end{array}$ & $\begin{array}{l}\text { Study } \\
\text { Objective }\end{array}$ & $\begin{array}{l}\text { Study } \\
\text { Design }\end{array}$ & $\begin{array}{l}\text { Study } \\
\text { Setting }\end{array}$ & $\begin{array}{l}\text { Sample } \\
\text { Size, } n\end{array}$ & Study Population & Primary Outcome & $\begin{array}{l}\text { Covariates } \\
\text { Adjusted } \\
\text { For }\end{array}$ & Findings & Comments \\
\hline $\begin{array}{l}\text { Collazo, } 2015 \\
\left({ }^{16}\right)\end{array}$ & $\begin{array}{l}\text { Report yield } \\
\text { of SC based } \\
\text { on } \\
\text { demographics }\end{array}$ & $\begin{array}{l}\text { Prospective } \\
\text { cross- } \\
\text { sectional } \\
\text { study }\end{array}$ & $\begin{array}{l}\text { Single urban } \\
\text { institution } \\
2004 \text { to } \\
2011\end{array}$ & $\begin{array}{l}37 \\
\text { Blacks } \\
\text { and } 43 \\
\text { Whites }\end{array}$ & $\begin{array}{l}\text { Uninsured and } \\
\text { underinsured average- } \\
\text { risk patients, age } \geq 50 \\
\text { years, undergoing SC. } \\
\text { Excluded: had a FOB } \\
\text { test within past year, } \\
\text { flexible sigmoidoscopy } \\
\text { within } 10 \text { years, history } \\
\text { of IBD, CRC, spoke } \\
\text { languages other than } \\
\text { English or Spanish } \\
\end{array}$ & $\begin{array}{l}\text { AA (an adenoma } \geq 1 \\
\text { cm in diameter, } \\
\text { villous/tubulovillous } \\
\text { histology, high- } \\
\text { grade dysplasia, or } \\
\text { cancer), PAA } \\
\text { (splenic flexure) }\end{array}$ & None & $\begin{array}{l}\text { No } \\
\text { difference } \\
\text { in AA or } \\
\text { PAA } \\
\text { prevalence }\end{array}$ & $\begin{array}{l}\text { Small sample } \\
\text { size, no } \\
\text { adjustment for } \\
\text { age and sex }\end{array}$ \\
\hline $\begin{array}{l}\text { Friedenberg, } \\
2012\left({ }^{17}\right)\end{array}$ & $\begin{array}{l}\text { Determine } \\
\text { and compare } \\
\text { yield of AA } \\
\text { and proximal } \\
\text { location }\end{array}$ & $\begin{array}{l}\text { Retrospective } \\
\text { cross- } \\
\text { sectional } \\
\text { study }\end{array}$ & $\begin{array}{l}\text { Single urban } \\
\text { institution } \\
2007 \text { to } \\
2010\end{array}$ & $\begin{array}{l}669 \\
\text { Blacks } \\
\text { and } 257 \\
\text { Whites }\end{array}$ & $\begin{array}{l}\text { Average-risk, } \\
\text { asymptomatic patients } \\
\text { age } 45 \text { to } 59 \text { with a } \\
\text { negative family history } \\
\text { of CRC and complete } \\
\text { SC with good/excellent } \\
\text { preparation. Excluded: } \\
\text { prior SC, colon } \\
\text { adenomas, or IBD }\end{array}$ & $\begin{array}{l}\text { AA (an adenoma } \\
>10 \mathrm{~mm} \text { in } \\
\text { diameter, villous } \\
\text { features or high- } \\
\text { grade dysplasia), } \\
\text { proximal adenoma } \\
\text { (splenic flexure) }\end{array}$ & $\begin{array}{l}\text { Age, sex, } \\
\text { BMI, } \\
\text { tobacco } \\
\text { use, regular } \\
\text { aspirin use, } \\
\text { statin use }\end{array}$ & $\begin{array}{l}\text { No } \\
\text { difference } \\
\text { in } A A \\
\text { prevalence }\end{array}$ & $\begin{array}{l}\text { Comparison } \\
\text { group of white } \\
\text { patients age } \\
45-49 \text { was not } \\
\text { available }\end{array}$ \\
\hline $\begin{array}{l}\text { Lebwohl, } \\
2012\left({ }^{18}\right)\end{array}$ & $\begin{array}{l}\text { Measure } \\
\text { adenoma } \\
\text { prevalence }\end{array}$ & $\begin{array}{l}\text { Retrospective } \\
\text { cross- } \\
\text { sectional } \\
\text { study }\end{array}$ & $\begin{array}{l}\text { Single urban } \\
\text { institution } \\
2006 \text { to } \\
2010\end{array}$ & $\begin{array}{l}591 \\
\text { Blacks } \\
\text { and } \\
3542 \\
\text { Whites }\end{array}$ & $\begin{array}{l}\text { Patients } \geq 50 \text { years } \\
\text { undergoing first-time } \\
\text { colonoscopy. } \\
\text { Excluded: incomplete } \\
\text { or prior colonoscopy, } \\
\text { poor bowel } \\
\text { preparation, personal } \\
\text { history of polyps, } \\
\text { indications of occult GI } \\
\text { blood loss, anemia, } \\
\text { history of neoplasia, } \\
\text { IBD, FAP or HNPCC }\end{array}$ & $\begin{array}{l}\text { AA (an adenoma } \\
\geq 10 \mathrm{~mm} \text { in greatest } \\
\text { diameter or } \\
\text { exhibiting advanced } \\
\text { histology such as } \\
\text { villous, tubulovillous } \\
\text { or high grade } \\
\text { dysplasia), PAA } \\
\text { (splenic flexure) }\end{array}$ & $\begin{array}{l}\text { Age, sex, } \\
\text { family } \\
\text { history of } \\
\text { colorectal } \\
\text { neoplasia }\end{array}$ & $\begin{array}{l}\text { Blacks have } \\
\text { a higher } \\
\text { prevalence } \\
\text { of AA and } \\
\text { PAA than } \\
\text { Whites }\end{array}$ & $\begin{array}{l}29 \% \text { of } \\
\text { subjects were } \\
\text { excluded due } \\
\text { to missing } \\
\text { data } \\
\text { pertaining to } \\
\text { race/ethnicity }\end{array}$ \\
\hline $\begin{array}{l}\text { Lieberman, } \\
2014\left({ }^{19}\right)\end{array}$ & $\begin{array}{l}\text { Measure } \\
\text { prevalence of } \\
\text { significant } \\
\text { polyps based } \\
\text { on } \\
\text { demographics }\end{array}$ & $\begin{array}{l}\text { Prospective } \\
\text { cross- } \\
\text { sectional } \\
\text { study }\end{array}$ & $\begin{array}{l}84 \text { practice } \\
\text { sites in the } \\
\text { US } 2000 \text { to } \\
2011\end{array}$ & $\begin{array}{l}17955 \\
\text { Blacks } \\
\text { and } \\
269160 \\
\text { Whites }\end{array}$ & $\begin{array}{l}\text { Average-risk patients } \\
\geq 40 \text { years undergoing } \\
\text { screening } \\
\text { colonoscopy. } \\
\text { Excluded: family } \\
\text { history of CRC or } \\
\text { polyps, positive FOB }\end{array}$ & $\begin{array}{l}\text { Large polyps } \\
\text { (polyps sized }>9 \mathrm{~mm} \\
\text { or described as a } \\
\text { tumor); large } \\
\text { proximal polyps } \\
\text { (splenic flexure) }\end{array}$ & Age, sex & $\begin{array}{l}\text { Blacks } \geq 50 \\
\text { have a } \\
\text { higher } \\
\text { prevalence } \\
\text { of large } \\
\text { polyps and } \\
\text { large }\end{array}$ & $\begin{array}{l}\text { No histology } \\
\text { of polyps } \\
\text { (poor } \\
\text { surrogate of } \\
\text { ACN), did not } \\
\text { state how } \\
\text { polyps were }\end{array}$ \\
\hline
\end{tabular}




\begin{tabular}{|c|c|c|c|c|c|c|c|c|c|}
\hline & & & & & $\begin{array}{l}\text { test, or any other lower } \\
\text { Gl symptoms }\end{array}$ & & & $\begin{array}{l}\text { proximal } \\
\text { polyps than } \\
\text { whites }\end{array}$ & $\begin{array}{l}\text { measured, } \\
\text { endoscopist } \\
\text { determined } \\
\text { race }\end{array}$ \\
\hline $\begin{array}{l}\text { Mendelsohn, } \\
2017\left({ }^{20}\right)\end{array}$ & $\begin{array}{l}\text { Compare } \\
\text { adenoma } \\
\text { yield }\end{array}$ & $\begin{array}{l}\text { Retrospective } \\
\text { cross- } \\
\text { sectional } \\
\text { study }\end{array}$ & $\begin{array}{l}\text { Single urban } \\
\text { institution, } \\
\text { time period } \\
\text { not stated }\end{array}$ & $\begin{array}{l}191 \\
\text { Blacks } \\
\text { and } 199 \\
\text { Whites }\end{array}$ & $\begin{array}{l}\text { Average-risk, } \\
\text { underserved patients } \\
40 \text { to } 69 \text { years of age } \\
\text { undergoing SC }\end{array}$ & $\begin{array}{l}\text { Adherence to } \\
\text { screening, any } \\
\text { adenoma, AA (no } \\
\text { definition given) }\end{array}$ & $\begin{array}{l}\text { Age, sex, } \\
\text { education, } \\
\text { smoking, } \\
\text { NSAID use, } \\
\text { obesity }\end{array}$ & $\begin{array}{l}\text { No } \\
\text { difference } \\
\text { in AA } \\
\text { prevalence }\end{array}$ & $\begin{array}{l}\text { Modest } \\
\text { sample size, } \\
\text { did not state } \\
\text { how race was } \\
\text { obtained }\end{array}$ \\
\hline $\begin{array}{l}\text { Schroy, } 2013 \\
\left({ }^{21}\right)\end{array}$ & $\begin{array}{l}\text { Define } \\
\text { prevalence } \\
\text { and location } \\
\text { of ACN }\end{array}$ & $\begin{array}{l}\text { Prospective } \\
\text { cross- } \\
\text { sectional } \\
\text { study }\end{array}$ & $\begin{array}{l}\text { Single urban } \\
\text { institution } \\
2005 \text { to } \\
2012\end{array}$ & $\begin{array}{l}1681 \\
\text { Blacks } \\
\text { and } \\
1172 \\
\text { Whites }\end{array}$ & $\begin{array}{l}\text { Asymptomatic, } \\
\text { average-risk patients } \\
\text { aged } 50 \text { to } 79 \\
\text { undergoing SC. } \\
\text { Excluded: prior polyps, } \\
\text { family history of CRC, } \\
\text { poor bowel } \\
\text { preparation, or } \\
\text { incomplete } \\
\text { examination }\end{array}$ & $\begin{array}{l}\text { Serrated lesions, } \\
\text { ACN (a tubular } \\
\text { adenoma } \geq 10 \mathrm{~mm} \text {, } \\
\text { villous features or } \\
\text { high-grade } \\
\text { dysplasia, } \\
\text { dysplastic serrated } \\
\text { lesion of any size, } \\
\text { or invasive cancer), } \\
\text { proximal ACN } \\
\text { (splenic flexure) }\end{array}$ & $\begin{array}{l}\text { Age, sex, } \\
\text { education, } \\
\text { insurance, } \\
\text { risk factors }\end{array}$ & $\begin{array}{l}\text { Whites } \\
\text { have a } \\
\text { higher } \\
\text { prevalence } \\
\text { of ACN } \\
\text { than } \\
\text { Blacks. No } \\
\text { difference } \\
\text { in proximal } \\
\text { ACN } \\
\text { prevalence }\end{array}$ & $\begin{array}{l}\text { Did not state } \\
\text { how race was } \\
\text { obtained }\end{array}$ \\
\hline $\begin{array}{l}\text { Stein, } 2010 \\
\left({ }^{22}\right)\end{array}$ & $\begin{array}{l}\text { Determine if } \\
\text { BMI is } \\
\text { associated } \\
\text { with ACN in a } \\
\text { diverse cohort }\end{array}$ & $\begin{array}{l}\text { Prospective } \\
\text { cross- } \\
\text { sectional } \\
\text { study }\end{array}$ & $\begin{array}{l}\text { Single } \\
\text { suburban } \\
\text { site } 2006 \text { to } \\
2007\end{array}$ & $\begin{array}{l}67 \\
\text { Blacks } \\
\text { and } 356 \\
\text { Whites }\end{array}$ & $\begin{array}{l}\text { Asymptomatic patients } \\
\text { aged } \geq 40 \text { years } \\
\text { undergoing SC. } \\
\text { Excluded: GI } \\
\text { symptoms, prior } \\
\text { history of colonic } \\
\text { neoplasia, IBD, prior } \\
\text { endoscopic screening } \\
\text { in } 10 \text { years }\end{array}$ & $\begin{array}{l}\text { ACN (large } \geq 1 \mathrm{~cm} \\
\text { adenoma, villous } \\
\text { adenoma ( }>25 \% \\
\text { villous, high grade } \\
\text { dysplasia or cancer) }\end{array}$ & None & $\begin{array}{l}\text { No } \\
\text { difference } \\
\text { in ACN } \\
\text { prevalence }\end{array}$ & $\begin{array}{l}\text { No } \\
\text { adjustment for } \\
\text { age and sex; } \\
\text { did not state } \\
\text { how race was } \\
\text { obtained }\end{array}$ \\
\hline $\begin{array}{l}\text { Wallace, } \\
2016\left({ }^{23}\right)\end{array}$ & $\begin{array}{l}\text { Assess } \\
\text { prevalence of } \\
\text { large bowel } \\
\text { polyps within } \\
\text { a diverse } \\
\text { population }\end{array}$ & $\begin{array}{l}\text { Prospective } \\
\text { cross- } \\
\text { sectional } \\
\text { study }\end{array}$ & $\begin{array}{l}\text { Regional } \\
\text { study } 2011 \\
\text { to } 2013\end{array}$ & $\begin{array}{l}110 \\
\text { Blacks } \\
\text { and } 91 \\
\text { Whites }\end{array}$ & $\begin{array}{l}\text { Uninsured, } \\
\text { asymptomatic patients } \\
\text { with no personal } \\
\text { history of colorectal } \\
\text { neoplasia between the } \\
\text { ages } 45 \text { to } 64 \text {. } \\
\text { Excluded: unable to } \\
\text { speak English or } \\
\text { cognitively unable to } \\
\text { provide informed } \\
\text { consent }\end{array}$ & $\begin{array}{l}\text { Serrated histology, } \\
\text { AA (adenomas with } \\
\text { at least } 25 \% \text { villous } \\
\text { component, high } \\
\text { grade dysplasia, or } \\
\text { an estimated size of } \\
\geq 1 \mathrm{~cm} \text { ), PAA (splenic } \\
\text { flexure) }\end{array}$ & $\begin{array}{l}\text { Age, sex, } \\
\text { clinical site }\end{array}$ & $\begin{array}{l}\text { No } \\
\text { difference } \\
\text { in AA or } \\
\text { PAA } \\
\text { prevalence }\end{array}$ & $\begin{array}{l}\text { Relatively } \\
\text { small sample } \\
\text { size and did } \\
\text { not state how } \\
\text { race was } \\
\text { obtained }\end{array}$ \\
\hline
\end{tabular}




\begin{tabular}{|c|c|c|c|c|c|c|c|c|c|}
\hline $\begin{array}{l}\text { Xirasagar, } \\
2014\left({ }^{24}\right)\end{array}$ & $\begin{array}{l}\text { Evaluate the } \\
\text { racial } \\
\text { disparities } \\
\text { reduction } \\
\text { potential of a } \\
\text { program for } \\
\text { indigent } \\
\text { persons }\end{array}$ & $\begin{array}{l}\text { Retrospective } \\
\text { cross- } \\
\text { sectional } \\
\text { study }\end{array}$ & $\begin{array}{l}\text { Multi-site } \\
\text { urban site } \\
2009 \text { to } \\
2010\end{array}$ & $\begin{array}{l}465 \\
\text { Blacks } \\
\text { and } 163 \\
\text { Whites }\end{array}$ & $\begin{array}{l}\text { Uninsured patients } \\
\text { with income }<200 \% \text { of } \\
\text { the federal poverty } \\
\text { limit, age } 45-64 \text { years } \\
\text { undergoing SC. } \\
\text { Excluded: GI } \\
\text { symptoms }\end{array}$ & $\begin{array}{l}\text { ACN (adenoma } \\
\geq 10 \mathrm{~mm} \text {, villous / } \\
\text { tubulovillous } \\
\text { features, high-grade } \\
\text { dysplasia, or } \\
\text { cancer) }\end{array}$ & None & $\begin{array}{l}\text { No } \\
\text { difference } \\
\text { in ACN } \\
\text { prevalence }\end{array}$ & $\begin{array}{l}\text { No } \\
\text { adjustment for } \\
\text { age and sex. } \\
\text { did not state } \\
\text { how race was } \\
\text { obtained }\end{array}$ \\
\hline
\end{tabular}

$\mathrm{AA}=$ advanced adenoma; PAA = proximal advanced adenoma $; \mathrm{CRC}=$ colorectal cancer; $\mathrm{SC}=$ screening colonoscopy; FOB = fecal occult blood; IBD = inflammatory bowel disease; HNPCC = hereditary non-polyposis colorectal cancer; $\mathrm{BMI}=$ body mass index; FAP = familial adenomatous polyposis 
Table 3. Summary of Study Results

\begin{tabular}{|c|c|c|c|c|c|c|c|c|}
\hline & & & $\begin{array}{l}\text { Prevalence } \\
\text { Range }\end{array}$ & $\begin{array}{l}\text { Prevale } \\
\text { Point E }\end{array}$ & $\begin{array}{l}\text { ce } \\
\text { timate }\end{array}$ & & & \\
\hline Outcome & $\begin{array}{l}\text { Study } \\
\text { N }\end{array}$ & $\begin{array}{l}\text { Subject } \\
N\end{array}$ & Blacks Whites & Blacks & Whites & $\begin{array}{l}\text { Risk } \\
\text { Difference } \\
(95 \% \mathrm{Cl})\end{array}$ & $\begin{array}{l}\text { Odds } \\
\text { Ratio } \\
(95 \% \mathrm{Cl})\end{array}$ & $\begin{array}{l}\mathrm{I}^{2} \text { test } \\
\text { Risk Difference } \\
\text { (RD), Odds Ratio } \\
\text { (OR) }\end{array}$ \\
\hline \multicolumn{9}{|l|}{$\mathrm{AA} / \mathrm{ACN}$} \\
\hline All studies & 9 & 296,749 & $2-10 \%$ & $6.57 \%$ & $6.20 \%$ & $\begin{array}{l}0.00(-0.01 \text { to } \\
0.02)\end{array}$ & $\begin{array}{l}1.03 \\
(0.81 \text { to } \\
1.30)\end{array}$ & $\begin{array}{l}51.9 \%(\mathrm{RD}) \\
55.9 \%(\mathrm{OR}) \\
\text { Moderate } \\
\end{array}$ \\
\hline $\begin{array}{l}\text { All studies } \\
\text { except } \\
\text { Lieberman } 2014\end{array}$ & 8 & 9634 & $5-12 \% \quad 2-10 \%$ & $5.95 \%$ & $6.11 \%$ & $\begin{array}{l}-0.001 \\
(-0.183 \text { to } \\
0.017)\end{array}$ & $\begin{array}{l}0.99 \\
(0.73 \text { to } \\
1.34)\end{array}$ & $\begin{array}{l}39.2 \%(\mathrm{RD}) \\
44.5 \%(\mathrm{OR}) \\
\text { Moderate }\end{array}$ \\
\hline Best subset $^{\dagger}$ & 5 & 8503 & $5-12 \%$ & $5.78 \%$ & $5.79 \%$ & $\begin{array}{l}0.002(-0.018 \\
\text { to } 0.022)\end{array}$ & $\begin{array}{l}1.06 \\
(0.75 \text { to } \\
1.50)\end{array}$ & $\begin{array}{l}\text { 49.8\% (RD) } \\
53.5 \%(\mathrm{OR}) \\
\text { Moderate }\end{array}$ \\
\hline \multicolumn{9}{|l|}{ Proximal AA/ACN } \\
\hline All studies & 5 & 299,761 & $2-9 \%$ & $3.30 \%$ & $2.42 \%$ & $\begin{array}{l}0.01 \text { ( } 0.00 \text { to } \\
0.01)\end{array}$ & $\begin{array}{l}1.20 \\
(1.12 \text { to } \\
1.30)\end{array}$ & $\begin{array}{l}0 \%(\mathrm{RD}) \\
0 \%(\mathrm{OR}) \\
\text { Low }\end{array}$ \\
\hline $\begin{array}{l}\text { All studies } \\
\text { except } \\
\text { Lieberman, } 2014\end{array}$ & 4 & 7267 & $2-9 \%$ & $2.64 \%$ & $1.93 \%$ & $\begin{array}{l}0.007(-0.004 \\
\text { to } 0.018)\end{array}$ & $\begin{array}{l}1.48 \\
(0.87 \text { to } \\
2.52)\end{array}$ & $\begin{array}{l}20.4 \%(\mathrm{RD}) \\
38.0 \%(\mathrm{OR}) \\
\text { Low to moderate }\end{array}$ \\
\hline Best subset $^{\star}$ & 3 & 7187 & $2-9 \%$ & $3.57 \%$ & $2.07 \%$ & $\begin{array}{l}0.006(-0.005 \\
\text { to } 0.018)\end{array}$ & $\begin{array}{l}1.44 \\
(0.84 \text { to } \\
2.49)\end{array}$ & $\begin{array}{l}27.4 \%(\mathrm{RD}) \\
47.4 \%(\mathrm{OR}) \\
\text { Moderate }\end{array}$ \\
\hline
\end{tabular}

${ }^{\dagger}$ Best subset includes references 17, 18, 20, 21, 23

*Best subset included references 18, 21, 23 
Figure Legend

Figure 1. Study Selection Flow Chart

Figure 2: A. Forest Plot for Advanced Adenoma - All studies;

Figure 2: B. Forest Plot for Proximal Advanced Adenoma - All Studies

Figure 3: Funnel Plot for Advanced Adenoma - All studies. 

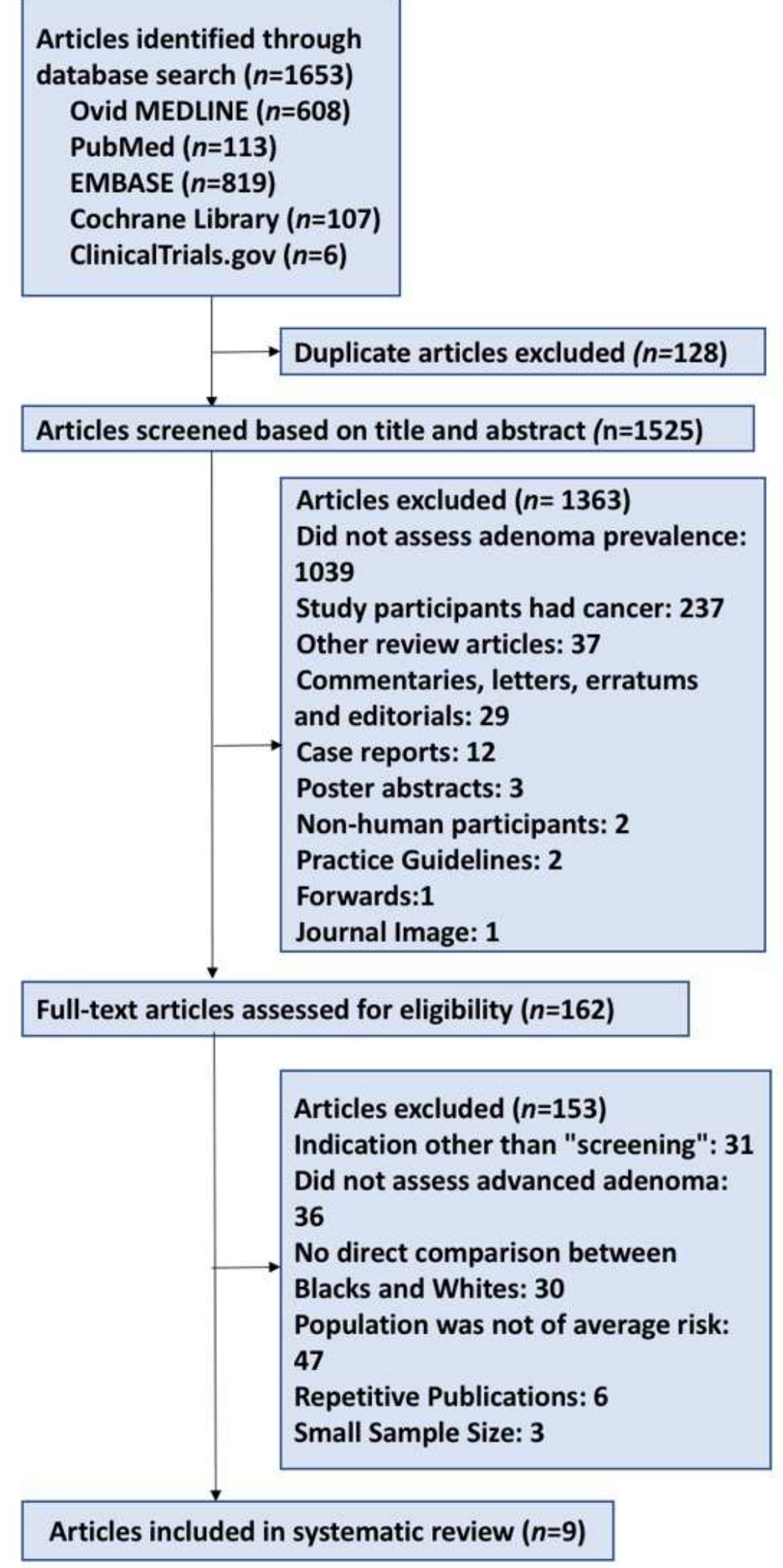
Author(s) and Year

Odds Ratio [95\% Cl]

\begin{tabular}{|c|c|c|c|c|c|c|c|c|}
\hline Collazo 2015 & & & & & & & $\rightarrow$ & $5.09[0.54,47.74]$ \\
\hline Friedenberg 2012 & & & & & & & & $0.91[0.52,1.61]$ \\
\hline Lebwohl 2012 & & - & $\longrightarrow$ & & & & & $1.48[0.99,2.20]$ \\
\hline Lieberman 2014 & & 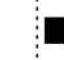 & & & & & & $1.15[1.08,1.21]$ \\
\hline Mendelsohn 2017 & & & & - & & & & $1.35[0.60,3.06]$ \\
\hline Schroy 2013 & & & & & & & & $0.72[0.52,0.98]$ \\
\hline Stein 2010 & & & & & & & & $0.81[0.27,2.39]$ \\
\hline Wallace 2016 & & & & & & & & $1.38[0.55,3.46]$ \\
\hline Xirasagar 2014 & & & & & & & & $0.61[0.33,1.14]$ \\
\hline & & & & & & & & $1.03[0.81,1.30]$ \\
\hline & $\Gamma$ & . & $T$ & $T$ & $T$ & $T$ & 7 & \\
\hline & 0 & 1 & 2 & 3 & 4 & 5 & 6 & \\
\hline
\end{tabular}


Author(s) and Year

Odds Ratio [95\% Cl]

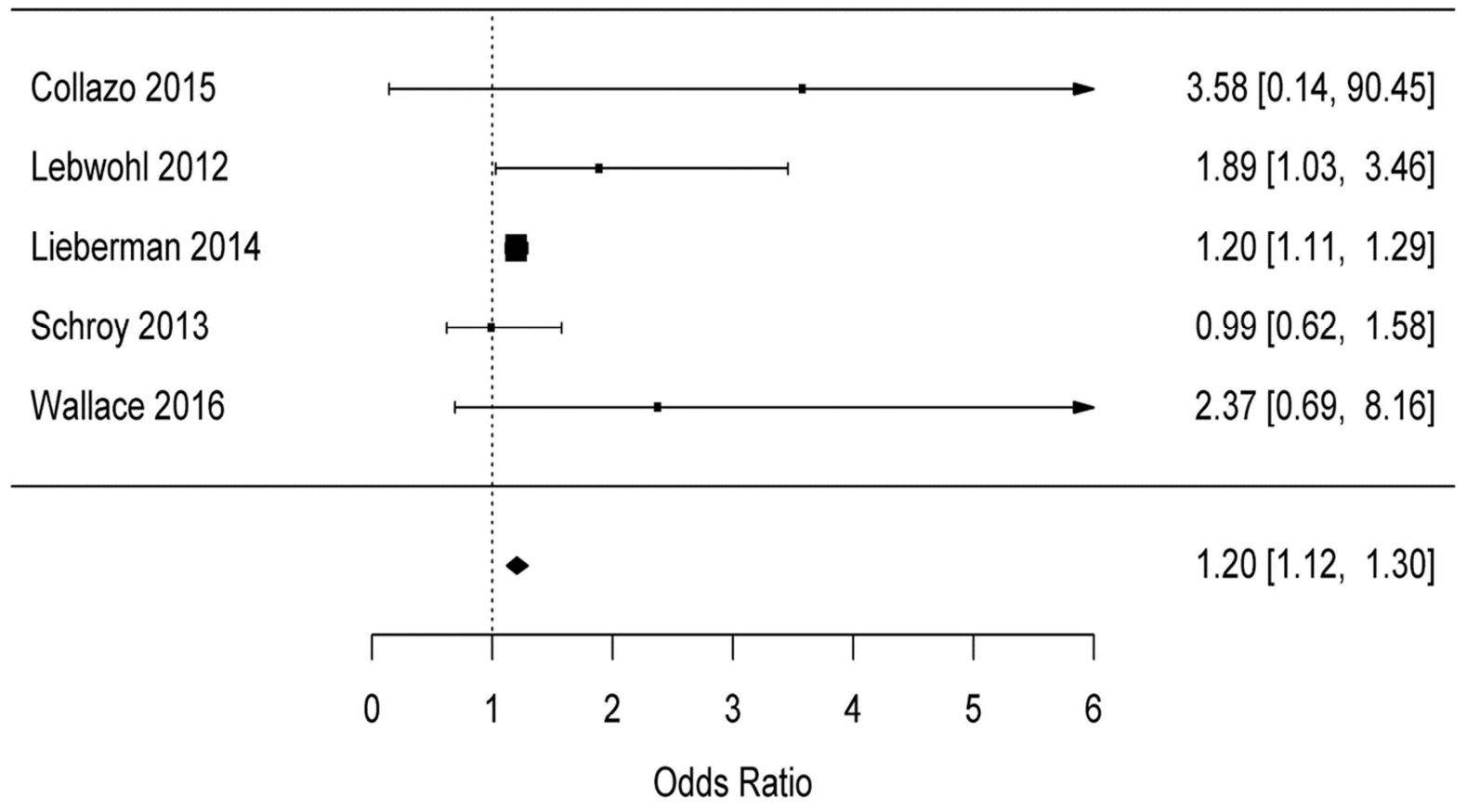




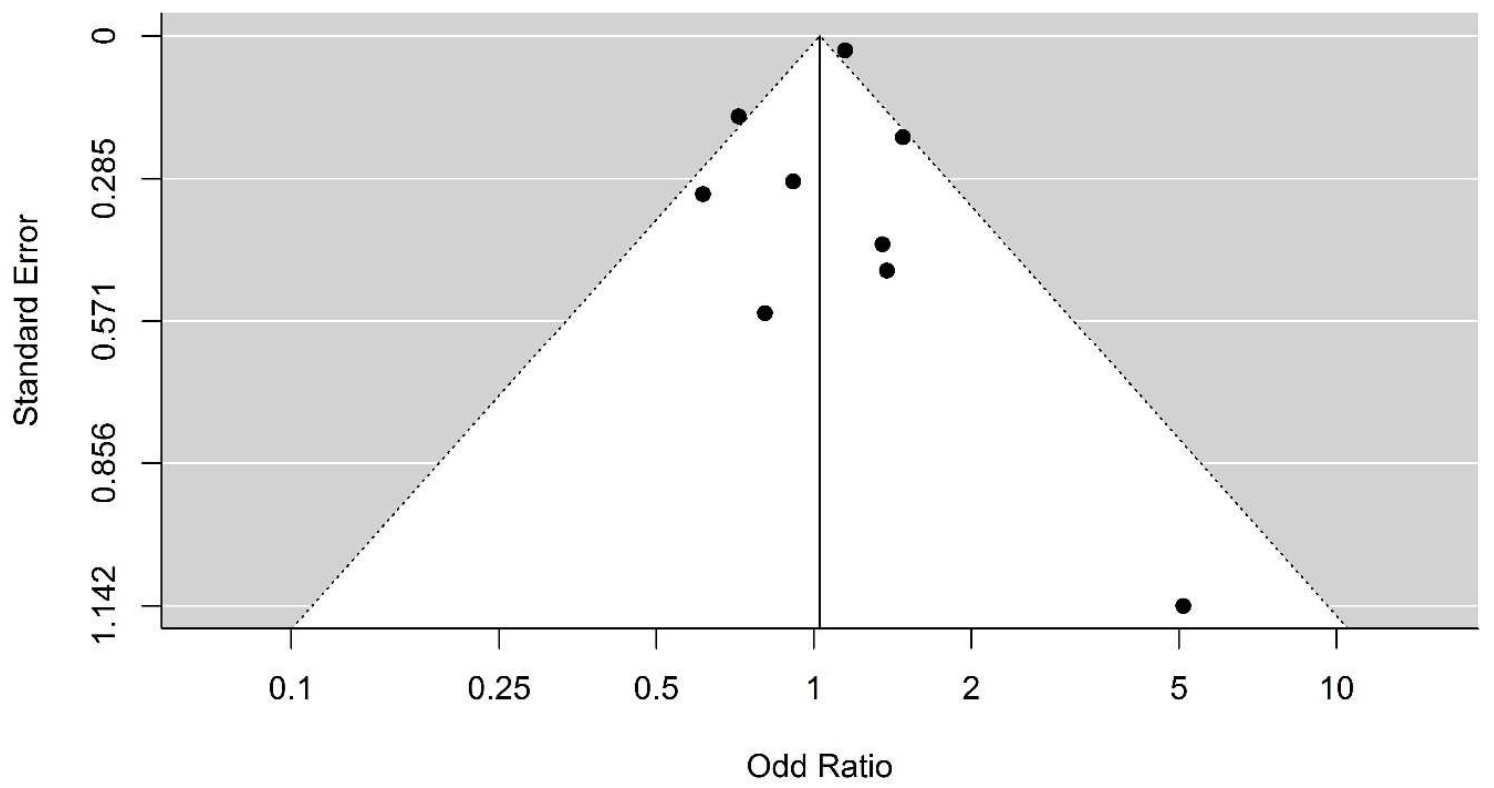




\section{Appendix: Detailed Search Strategies}

\section{MEDLINE (Ovid):}

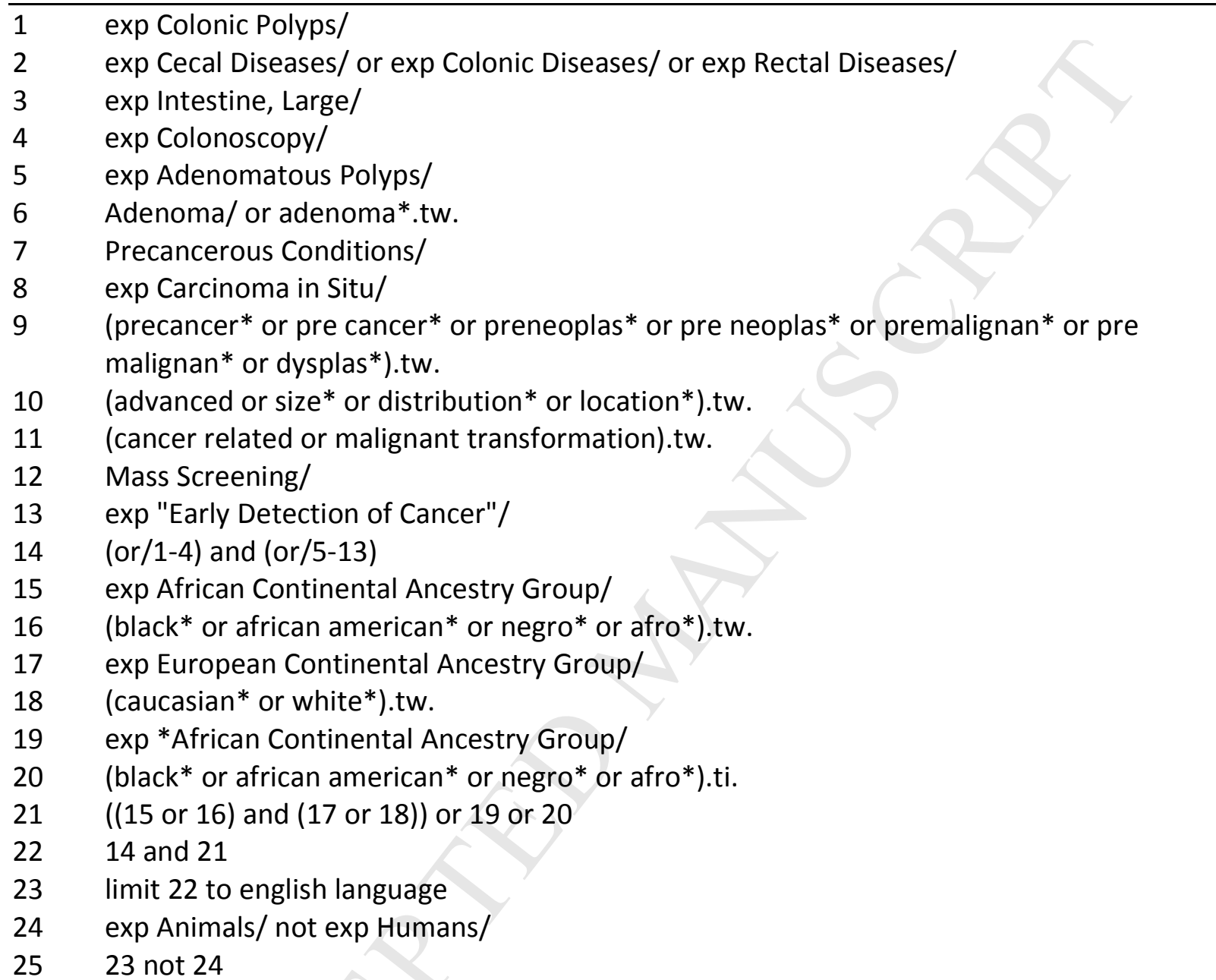

\section{PubMed (PubMed.gov):}

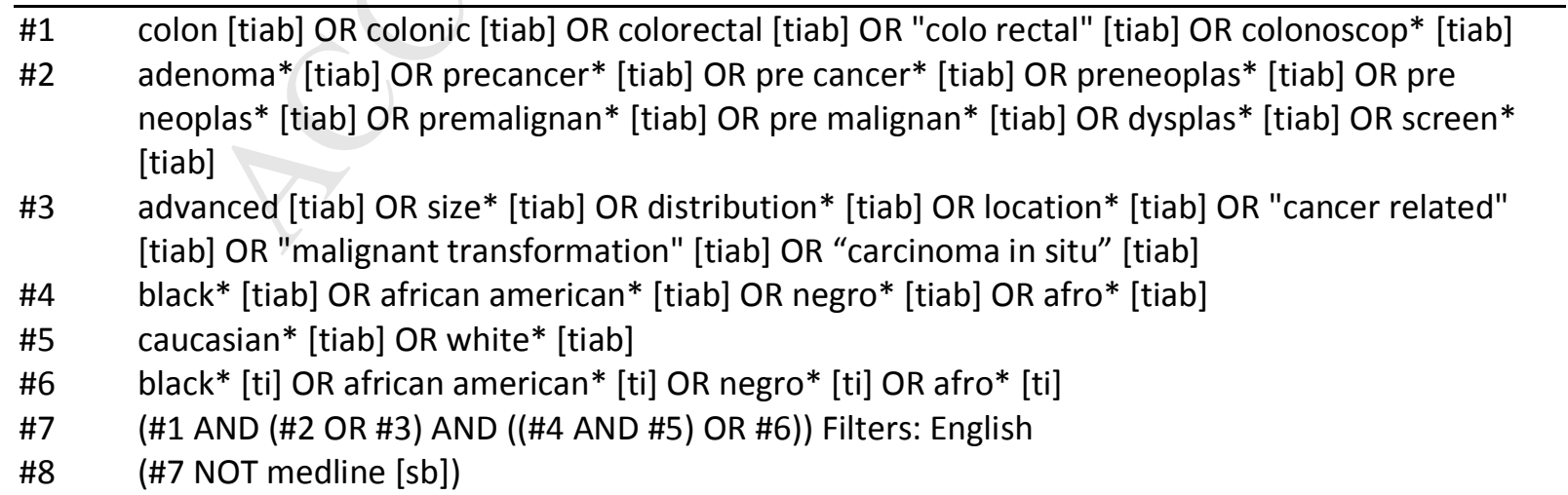




\section{EMBASE (Embase.com):}

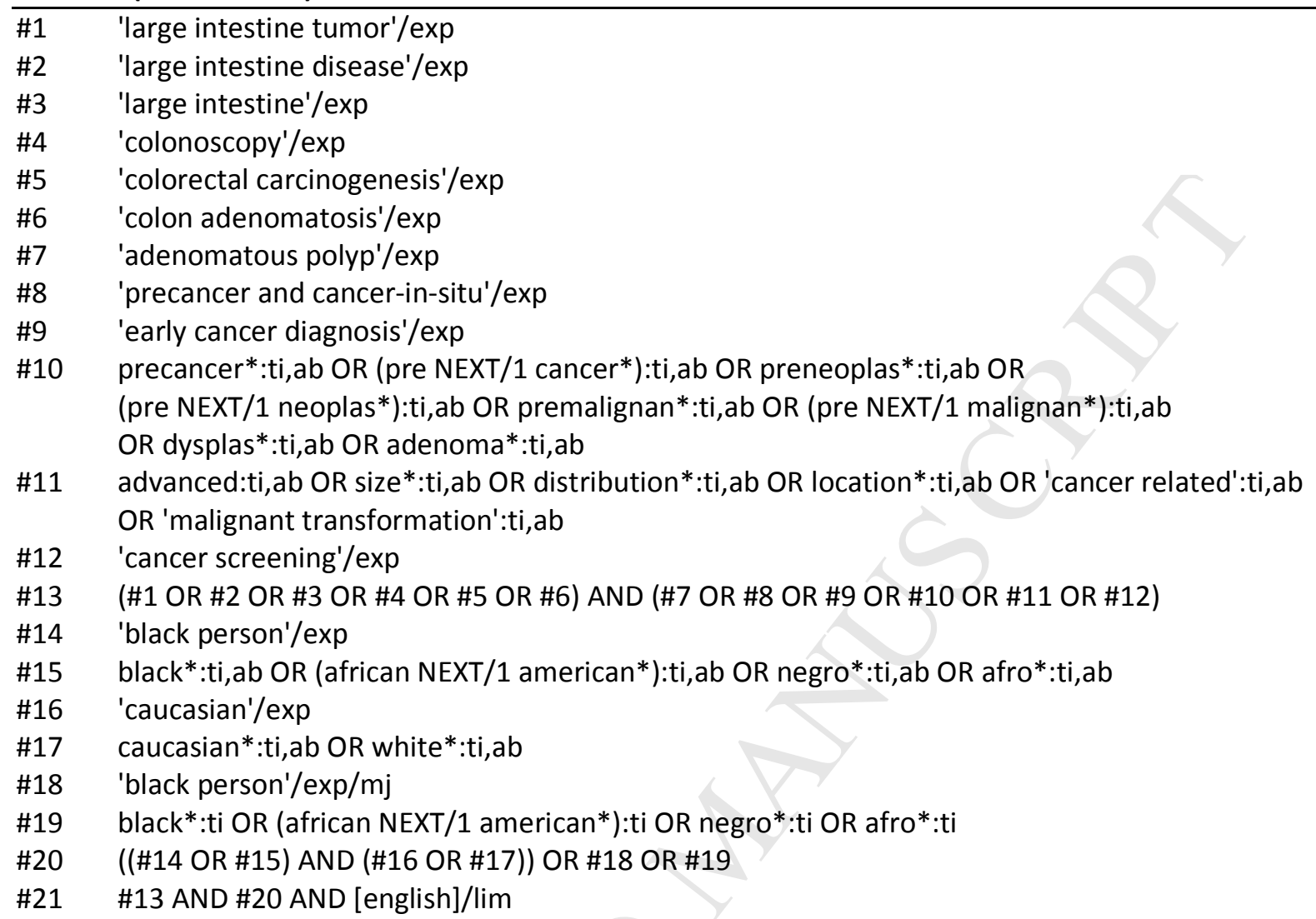

\section{Cochrane Library (Wiley):}

\#1 (colon or colonic or colorectal or colo next rectal or colonoscop*):ti,ab,kw

\#2 (precancer* or pre next cancer* or preneoplas* or pre next neoplas* or premalignan* or pre next malignan* or dysplas* or screen* or adenoma*):ti,ab,kw

\#3 (advanced or size* or distribution* or location* or "cancer related" or "malignant transformation" or "carcinoma in situ"):ti,ab,kw

\#4 (black* or african next american* or negro* or afro*):ti,ab,kw

\#5 (caucasian* or white*):ti,ab,kw

\#6 (black* or african next american* or negro* or afro*):ti

$\# 7 \quad \# 1$ and (\#2 or \#3) and ((\#4 and \#5) or \#6) 